\title{
Dertig jaar gratis kranten in Nederland. Voorlopers, opkomst en neergang
}

Lezers en adverteerders laten in de 2Ie eeuw dagbladen in de steek; digitale media nemen de rol van traditionele kranten over. Toch werd in 2007 in Nederland de hoogste dagbladoplage ooit gerealiseerd: 5.5 miljoen kranten per dag. Een derde daarvan bestond uit gratis dagbladen, een mediavorm die hier in 1999 geïntroduceerd werd, een snelle opkomst beleefde, en ook snel weer aan belang inboette. Dit artikel beschrijft de opkomst van gratis kranten in Nederland in kaart gebracht. Hoe is deze ontwikkeling te plaatsen binnen een Europese context, wat hebben deze kranten betekend voor de dagbladenmarkt in het algemeen en het lezen van kranten in het bijzonder?

Dit artikel beschrijft eerst mogelijke theoretische modellen waarmee de opkomst (en ondergang) van gratis kranten verklaard kan worden. Vervolgens wordt de 'prehistorie' van gratis kranten (vóór de komst van Metro Stockholm in 1995) en de mondiale opkomst van gratis kranten vanaf 1995 belicht. Speciale aandacht is er voor de ontwikkelingen op het Europese continent, omdat de Nederlandse voor een belangrijk deel parallel loopt aan die in andere Europese markten. Vervolgens staat de ontstaansgeschiedenis van de acht 'moderne' Nederlandse gratis kranten centraal. Daarna wordt ingegaan op hun oplage en bereik in de context van die van alle Nederlandse dagbladen. Welke verbanden er tussen die ontwikkelingen zijn en in hoeverre theoretische inzichten die in het begin zijn geformuleerd verklarende inzichten opleveren, zal in de conclusie worden besproken.

\section{Een theoretisch raamwerk}

Het theoretisch raamwerk waarin de ontwikkeling van dagbladen kan worden geplaatst is doorgaans sociaal-politiek van karakter. Bij de liberale, socialistische, katholieke en protestantse pers speelden politieke verhoudingen, emancipatie van bevolkingsgroepen, journalistieke idealen, politieke partijen, belangengroeperingen en religieuze organisaties een belangrijke rol. ${ }^{\mathrm{I}}$ Een krant ontstond, veranderde en ging soms ten onder te midden van een politiek en sociaal krachtenveld waarbij de journalistieke signatuur een belangrijke rol speelde. Bij de meer commerciële pers domineerden economische krachten naast journalistieke motieven. ${ }^{2}$ Voor de 
opkomst van gratis dagbladen zijn deze theoretische inzichten nauwelijks bruikbaar, omdat deze door uitgevers vrijwel uitsluitend werden ingezet vanuit bedrijfsmatige motieven: het ging om marktverovering of -bescherming.

Inzichten vanuit de economie zijn dan ook belangrijker in dit geval. Een model dat oplageontwikkelingen bij dagbladen kan verklaren, is het life cycle model dat werd ontwikkeld in de jaren zestig van de vorige eeuw om veranderingen in de internationale handel te beschrijven. ${ }^{3}$ Van Zuilen gebruikte het model voor de Amerikaanse magazinemarkt. ${ }^{4}$ Picard stelt dat de krantenmarkt 'seems to be following a basic industry life cycle pattern'. ${ }^{5}$ Binnen het model worden vier fasen onderscheiden: introductie, groei, volwassenheid en krimp. In Nederland - en ook in vrijwel alle andere West-Europese landen is sprake van verzadiging (stabiele oplage) in de laatste twee decennia van de twintigste eeuw. Rond 2000 is er veelal sprake van krimp. ${ }^{6}$ Een belangrijke oorzaak is dat kranten er steeds moeilijker in slagen jonge lezers te trekken, aangezien die een ander mediagedrag hebben ontwikkeld; zij zijn immers niet opgegroeid met kranten, maar met tv of internet. ${ }^{7}$

Voor dagbladuitgevers zou een gratis krant een kans zijn om hun product te diversifiëren en een jonger publiek te bereiken. In de praktijk brachten bestaande uitgevers echter pas gratis kranten uit nadat entrepreneurs dergelijke producten op de markt brachten of dat dreigden te gaan doen. Een mogelijke verklaring voor deze trage reactie levert Christensen die in The Innovator's Dilemma stelt dat traditionele aanbieders van producten vooral investeren in verbeteringen, niet in mogelijk marktverstorende (disruptieve) innovaties. ${ }^{8}$ Zo'n innovatief product is over het algemeen simpeler, goedkoper en toegankelijker voor nieuwe consumenten. Wat dat betreft is een gratis krant een schoolvoorbeeld van een disruptieve innovatie.

Een belangrijke vraag voor uitgevers is of gratis kranten een substituut kunnen zijn voor betaalde versies. Dimmick en Rothenbuhler stellen dat media over het algemeen hun eigen 'niche' opzoeken: een afwijkend product met een afwijkende markt in vergelijking met andere producten. ${ }^{9}$ Dat zou ook voor dit specifieke product gelden. Pas als producten perfecte substituten zijn - dezelfde producteigenschappen en dezelfde doelgroep - is er kans op substantiële substitutie. Dit betekent dat gratis kranten veel meer met elkaar concurreren dan met betaalde producten. De substitutie zou dan beperkt zijn.

Gratis kranten kunnen zich ook niet aan de levenscyclus onttrekken, een cyclus die in hun geval kort was. Overal in Europa dalen in de tweede helft van het eerste decennium van de 2Ie eeuw de oplagen van deze kranten. ${ }^{\circ}$ De traditionele (jonge) lezer van deze krant heeft dan inmiddels de beschikking over alternatieve (mobiele) media.

\section{Methode en bronnen}

Het gedeelte van dit artikel dat de internationale en historische context behandelt, is gebaseerd op eigen onderzoek. Data over titels en oplagen zijn verzameld bij de instanties die oplagen controleren en de uitgeversorganisaties in de desbetreffende landen. Waar nodig is informatie aangevuld door de gegevens van uitgevers en titels separaat te controleren. Voor het Nederlandse gedeelte wordt gebruikgemaakt van oplagegegevens van het Oplage Instituur (HOI) dat deze gegevens vanaf I999 verzamelt; oudere gegevens komen van het Cebuco, de marketingafdeling van de organisatie van Nederlandse krantenuitgevers NDP. Waar nodig zijn 
gegevens van uitgevers zelf of uit vakbladen geraadpleegd. HOI, een organisatie waarin uitgevers, adverteerders en mediabureaus participeren, verzamelt cijfers op basis van gecontroleerde accountantsgegevens. Het bereik (leesgedrag) wordt gerapporteerd op basis van de rapportages van de Noм Print Monitor. Deze gegevens worden verzameld op basis van een survey onder ruim 20.000 Nederlanders van dertien jaar en ouder. Het betreft altijd het 'dagelijks' gebruik. Ter aanvulling van deze gegevens en het literatuuronderzoek zijn drie interviews gehouden met voormalige hoofdredacteuren van Metro en Spits.

\section{De 'prehistorie': gratis kranten vóór 1995}

De mondiale gratis-krantenrevolutie begon op I3 februari I995 in Stockholm. Snel kregen uitgevers overal ter wereld in de gaten dat daar iets bijzonders gebeurde; ze reisden af naar de Zweedse hoofdstad om het wonder van een gratis dagblad te aanschouwen.

Zoals elke revolutie had ook deze zijn voorlopers. Vóór I995 waren er ruim twintig pogingen om kranten gratis te verspreiden - dagbladen ${ }^{\text {II }}$ welteverstaan, geen wekelijkse gratis advertentiebladen. De oudste van deze pogingen dateert uit het eind van de negentiende eeuw, zelfs Nederland kende een voorvoorloper. Het oudste gratis dagblad dateert uit I885, in dat jaar ging de General-Anzeiger für Lübeck und Umgebung dagelijks verschijnen. Nog voor de eeuwwisseling werd de krant omgezet naar een betaalde titel. ${ }^{\mathrm{I2}}$ In I906 werd de eerste gratis forensenkrant gelanceerd in Australië; the Manly Daily werd dagelijks - tot aan vandaag uitgedeeld op de veerboten naar Sydney. De krant is nu onderdeel van Murdoch's News Ltd. Van 23 tot 29 april I945 publiceerde Joseph Goebbels' propaganda-ministerie gratis Der Panzerbär - Kampfblatt für die Verteideger Gröss-Berlin via het Deutsche Verlag. De lezers werd gevraagd de krant na lezen door te geven: 'Lesen und Weitergeben!'13

$\mathrm{Na}$ de Tweede Wereldoorlog kwamen er in de Verenigde Staten gratis lokale kranten, vooral in kleinere plaatsen in Californië, Colorado en New Hampshire. Het ging in totaal om elf titels waarvan er nog steeds enkele bestaan. In Brazilië begon in 1974 MetroNews als de eerste grootstedelijke gratis krant die via het openbaar vervoer werd verspreid. In I994 hield de gratis avondkrant Tonight het slechts enkele maanden uit in London. ${ }^{\mathrm{I}}{ }^{\text {The Moscow Times in }}$ de Russische hoofdstad (I992) was gericht op expats en zakenlieden, een van de oprichters was voormalig Nieuwe Revu verslaggever Derk Sauer, tegenwoordig mede-eigenaar van NRC Handelsblad.

De echte Nederlandse bijdrage aan de prehistorie van gratis kranten was het Eindhovens Nieuwsblad, dat als tegenhanger van het Eindhovens Dagblad werd gelanceerd op 2I maart I983. ${ }^{\text {I5 }}$ De broadsheet-krant, die huis aan huis werd verspreid, was opgericht door vastgoedhandelaar Huub Schalkwijk. De drukkosten waren hoog, de bezorging liet te wensen over, terwijl de adverteerder het liet afweten; op I3 april stopte de krant. Bij de lancering waren de ambities groot, de krant telde 45 personeelsleden, onder wie 25 journalisten.

De eerste, voornamelijk kleinstedelijke, pogingen waren het initiatief van lokale uitgevers alleen de kranten in Sao Paolo (I974) en London (1994) kunnen als voorlopers van de forenzenkrant van de jaren negentig worden beschouwd. Het typische format van de huidige gratis kranten - een tabloid met nadruk op kort nieuws voor een jong publiek - had zich voor zover we kunnen nagaan, nog niet ontwikkeld. Van niet alle kranten zijn exemplaren 
Tabel I. Gratis dagbladen van vóór de introductie van Metro Stockholm.

\begin{tabular}{|c|c|c|}
\hline Titel & Verschijningsgebied & Periode \\
\hline General-Anzeiger für Lübeck und Umgebung & Lübeck (Duitsland) & $\mathrm{I} 885- \pm \mathrm{I} 895$ \\
\hline Manly Daily & Manly (Australië) & $1906-$ \\
\hline Der Panzerbär & Berlin (Duitsland) & I945 \\
\hline Contra Costa News & Walnut Creek (VS) & 1947 - I960s \\
\hline Colorado Daily & Boulder (VS) & $1970-$ \\
\hline MetroNews & Sao Paulo (Brazilië) & I974 - \\
\hline Aspen Daily News & Aspen (VS) & I978- \\
\hline Jackson Hole Daily & Jackson Hole (VS) & I978 - \\
\hline Vail Daily & Vail (VS) & I98I - \\
\hline Eindhovens Nieuwsblad & Eindhoven (Nederland) & I983 \\
\hline Birmingham Daily News & Birmingham (Groot Brittannië) & I984 - I992 \\
\hline Keizai no Densho-bato & Kitami (Japan) & $1987-$ \\
\hline Aspen Times & Aspen (VS) & I988 - \\
\hline Steamboat Today & Steamboat Springs (VS) & $1989-$ \\
\hline Conway Daily Sun & Conway (VS) & $1989-$ \\
\hline Summit Daily News & Summit County (VS) & I990 - \\
\hline Moscow Times & Moscow (Rusland) & I992 - \\
\hline Mini Diario & Valencia (Spanje) & I992-2008 \\
\hline The Leader & Klang Valley (Maleisië) & I993 - I994 \\
\hline Berlin Daily Sun & Berlin (VS) & I994 - \\
\hline Tonight & London (Groot Brittannië) & I994 \\
\hline Palo Alto Daily News & Palo Alto (VS) & $1995-2013$ \\
\hline
\end{tabular}

beschikbaar, maar van de nog bestaande titels zijn vaak de eerste nummers online opgenomen. Het Persmuseum in Amsterdam beschikt over een exemplaar van het Eindhovens Nieuwsblad: een traditionele broadsheet die vooral leek op z'n concurrent, het Eindhovens Dagblad.

\section{De gratis revolutie, een mondiaal fenomeen}

Metro Stockholm was het startschot voor een wereldomvattende vloedgolf aan gratis kranten. Op het hoogtepunt in 2007/2008 ging het wereldwijd om een oplage van ruim 40 miljoen in zestig landen, gerealiseerd door 275 titels. In veel landen waren gratis kranten goed voor een marktaandeel van 30 procent of meer. In tegenstelling tot de eerdere initiatieven waren het vooral de internationaal georiënteerde uitgevers en grote nationale krantenbedrijven die het speelveld beheersten.

Metro Stockholm werd uitgegeven door de Modern Times Group, onderdeel van industrie- en mediabedrijf Kinnevik. Krantenuitgevers, de ondergrondse van Stockholm en diverse financiële instellingen wilden niet investeren in de onderneming. ${ }^{16}$ In 1997 lanceerde Metro International in Tsjechië de gratis krant en vervolgens in Hongarije, Finland, Nederland, Griekenland, Italië, Polen, Zwitserland, Groot-Brittannië, Argentinië, Canada, Chili, de Verenigde Staten, Denemarken, Spanje, Frankrijk, Korea, Hong Kong, Portugal, Rusland, Kroatië, Mexico, Brazilië, Ecuador, Guatemala, Colombia, Peru, Nicaragua en Puerto Rico. In 2007 had Metro meer dan zeventig edities in 2I landen. In 20I4 waren er Metro-titels in ruim twintig landen, maar in vrijwel alle gevallen zijn het franchise-ondernemingen die door lokale uitgevers worden geëxploiteerd. In Europa is Metro alleen nog meerderheidsaandeelhouder bij de Zweedse editie.

De expansiedrift van Metro inspireerde wereldwijd. Uitgevers volgden het voorbeeld soms om de eigen markt te beschermen, maar ook entrepreneurs brachten gratis kranten uit. ${ }^{17}$ In het 
begin van deze eeuw - na de schrik van de dot.com-crisis - groeide de economie sterk, waardoor de advertentiemarkt veelbelovend was. Gratis kranten hebben aanzienlijk minder kosten dan een betaalde krant: een kleinere staf, distributie geconcentreerd in het openbaar vervoer, en geen eigen drukkerij.

Wereldwijd groeide de oplage tot 42 miljoen en het aantal titels tot 275 (in zestig landen). $\mathrm{Na} 2008$ zette vooral in Europa de daling in. In Azië groeide de oplage naar zo'n 9 miljoen. Op het Amerikaanse continent daalt de oplage in Canada en de Verenigde Staten enigszins, maar is er een groei in Latijns Amerika.

De gratis kranten die vanaf de tweede helft van de jaren negentig verschenen, weken op belangrijke punten af van traditionele kranten. Zo verschenen ze allemaal in tabloid-formaat, wat tot dusver ongebruikelijk was in de meeste Europese landen, behalve voor de boulevardpers. Bovendien was hun omvang beperkt (tussen de I6 en 32 pagina's), omdat het expliciet de bedoeling was dat lezers tijdens hun reis van huis naar werk of school de krant uit zouden kunnen lezen. ${ }^{\mathrm{I}}{ }^{8}$ De nieuwe generatie gratis kranten verscheen niet in het weekend en ontbeerden dus ook de weekendbijlagen; de inhoud bestond uit kort nieuws met relatief veel nadruk op entertainment, service en ander licht verteerbaar materiaal. De voornaamste doelgroep was de jongere lezer. Vogel stelt in zijn analyse van de gratis kranten die tussen I998 en 200I in Duitsland verschenen dat deze 'optisch und inhaltlich optimiert und auf die Zielgruppe der I4- bis 29-Jährigen ausgerichtet' waren. ${ }^{\text {I9 }}$

De inhoudelijke focus op 'licht' materiaal resulteerde ook in veel kritiek op de inhoud van kranten. Wilcox citeert in haar analyse van de opkomst van gratis kranten in Frankrijk commentaren uit Le Monde, L'Humanite en Libération. De laatste schreef: 'fiez-vous des contrefaçons ... le recours au papier journal ne suffit pas à faire un quotidien d'information.' L'Humanite kwalificeerde de gratis kranten als 'fast food' terwijl Jean- Marie Colombani van Le Monde de ondergang van de kwaliteitsjournalistiek voorspelde als gratis kranten zouden worden toegestaan (wat Le Monde overigens niet belette om vervolgens een contract af te sluiten om de gratis kranten te drukken). ${ }^{20}$

Of die inhoud inderdaad zo oppervlakkig is, kan slechts door inhoudsanalyse worden aangetoond. Kammer verrichtte een dergelijk onderzoek in Denemarken, waar op een gegeven moment negen gratis kranten verschenen. Hij concludeerde dat gratis kranten weliswaar minder politieke berichtgeving bevatten dan 'kwaliteitskranten', maar meer dan de tabloids die Denemarken kent. ${ }^{21}$

\section{Het Europese perspectief}

Voor Nederland is de Europese context relevant. In vrijwel elk land zijn de afgelopen twintig jaar gratis kranten gelanceerd. Figuur I laat zien dat 2006-2008 de topjaren waren; de oplage kwam boven de 25 miljoen, gerealiseerd door zo'n 135 titels in ruim dertig landen. In Denemarken, Spanje, Oostenrijk, Frankrijk, IJsland, Italië, Andorra, Letland, Luxemburg, Macedonië, Nederland, Portugal en Zwitserland lag het marktaandeel van gratis kranten boven de 25 procent. Gratis dagbladen zijn echter extreem gevoelig voor de conjunctuur, wat zich manifesteerde in een afvlakking van de groei in 2002 en 2003 , een opleving daarna, en een 


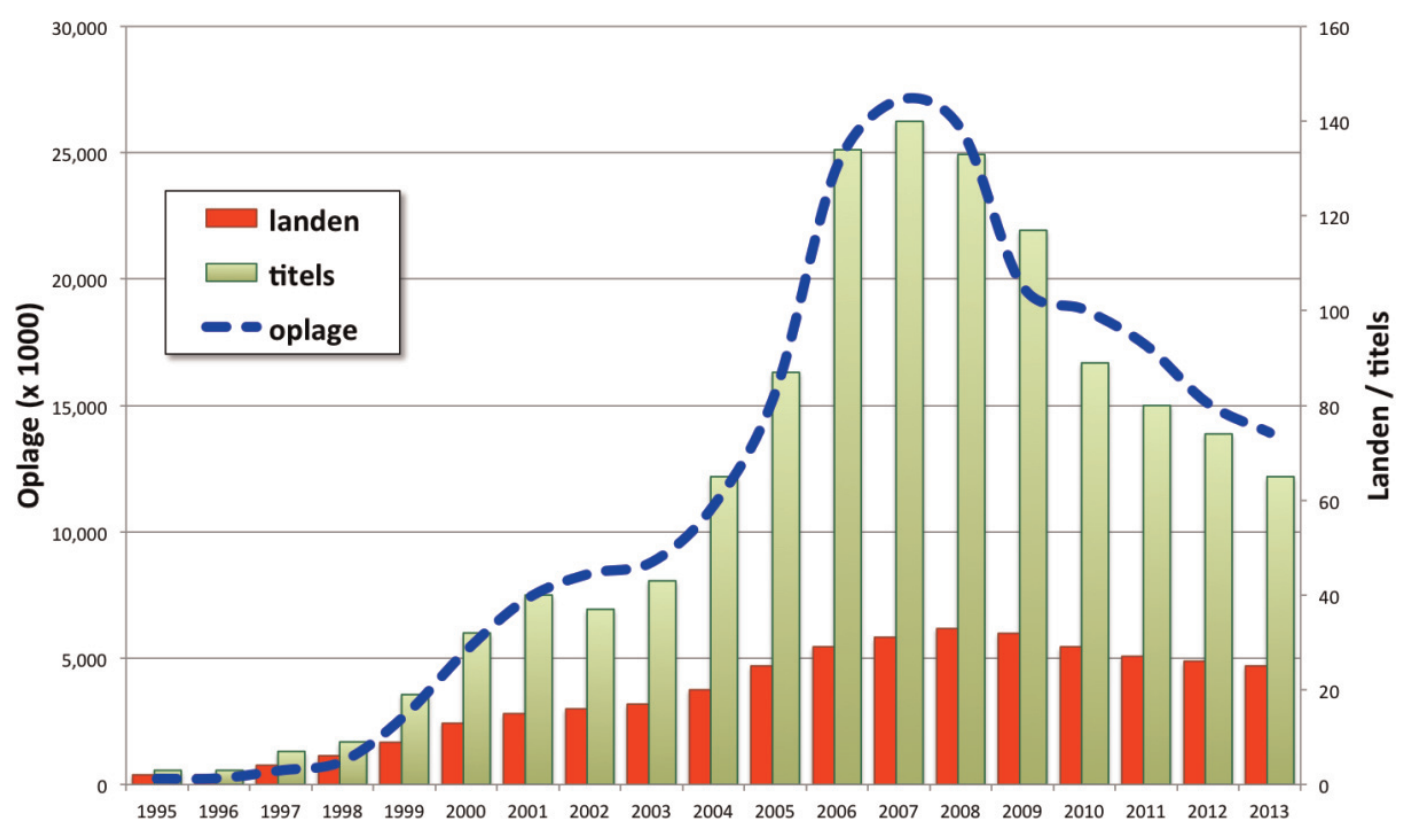

Figuur I. Gratis dagbladen in Europa.

Bron: eigen onderzoek.

scherpe daling na 2008: het aantal titels halveerde in vijf jaar en de overblijvende titels gingen terug in oplage.

Tot 2006 waren er twee tot drie gratis titels per land; in 2007 steeg dat aantal tot vijf. Niet alle titels kenden nationale verspreiding, maar in grote steden concurreerden vaak drie of meer titels. Dit treffen we aan in Nederland, Denemarken, Spanje, Frankrijk, Groot Brittannië, Zwitserland, Zweden, Italië, Griekenland en Portugal. Nederland kende op dat moment vier gratis kranten: Metro, Spits, De Pers en DAG. Omdat gratis dagbladen vooral met elkaar concurreren - ze hebben vergelijkbare doelgroepen - leidt dat tot minder lezers per titel en ook tot lage advertentietarieven. Samen met de economische crisis was dat een fatale combinatie: adverteerders verlaagden hun advertentiebudgetten en eisten extra lage tarieven.

De ontwikkeling in Nederland - met groei tot 2008 en sterke consolidatie in de periode daarna - zien we terug in andere markten waar de mediastructuur, vooral de positie van dagbladen, grote overeenkomsten vertoont met ons land: België, Scandinavië, Duitssprekende landen en Engelstalige landen. ${ }^{22}$ In die markten maakte concurrentie - soms tussen drie, vier of vijf titels - altijd plaats voor een mono- of duopolie. ${ }^{23}$

\section{Nederland: Metro en Spits}

Op 2I juni 1999 werden in Nederland Metro en Spits gelanceerd. Bij Metro had de uitgever vanaf het begin al Europese expansieplannen; bij Spits lagen de plannen ook al langer klaar, maar De Telegraaf zag een gratis krant als een bedreiging voor de eigen titel; zo'n titel moest vooral defensief ingezet worden. Aanvankelijk zouden ze allebei in september gelanceerd worden (begin voetbalseizoen, aanvang scholen en universiteiten), maar omdat beide titels de eerste wilden zijn, verschoof de lancering van de twee kranten naar het begin van de advertentie-luwe zomer, 2I juni. 
Bijna Io procent van de aandelen (9.9\%) van Metro was in handen van drie particulieren: Tiago Jurgens, Bart Lubbers en Falk Madeja. Zij waren actief betrokken bij de ontwikkeling van de Nederlandse editie. In 2005 werden zij - na slepende rechtszaken - uitgekocht door Metro. In 2012 verkocht de Zweedse eigenaar Metro aan de Telegraaf Media Groep, uitgever van concurrent Spits.

De eerste jaren werd Metro door problemen geplaagd. In 200I botsten hoofdkantoor en de Nederlandse vestiging over het redactionele beleid. Ook was men ontevreden over de verkoopresultaten, wat tot een bezuinigingsronde leidde. Volgens Sakari Pitkänen, die door het Londense hoofdkantoor naar Amsterdam werd gestuurd om de rust te herstellen, wilde de redactie een soort Volkskrant maken, met veel nieuws uit de Derde Wereld. Bovendien werd regelmatig met staking gedreigd. Dat leidde tot spanningen op de redactie, maar ook tot onenigheid tussen de redactie en de advertentieverkoop, waardoor de resultaten onder druk kwamen te staan. ${ }^{24}$ Hoofdredacteur Jelle Leenes en een deel van de redactie verdwenen onder druk van het Londense hoofdkantoor. Pitännen nam zelf voor enkele weken het roer over; Metro had toen een hoofdredacteur die geen Nederlands sprak. De opvolger van Pitännen werd Jan Dijkgraaf:

'Ik trof een zeer defensief clubje redacteuren, en heb mensen die niet mee wilden in mijn lijn een voor een zien vertrekken. Toen ik eindredacteuren aanstelde die ik zelf koos, was het gebeurd met de oppositie. We introduceerden vervolgens commercieel aantrekkelijke rubrieken als werk, geldzaken, ICT/gadgets, wonen, auto's die de vorige redactie maar vies vond. De stakingsdreiging werd gesteund door de NVJ. We hebben die buitenspel gezet door de redactieraad te vragen waar het ze om ging. Het bleek om geld en vrije tijd te gaan. Dat hebben we geregeld waardoor de NVJ niet meer namens de redactie dingen ging eisen. ${ }^{25}$

In 2003, twee jaar na de komst van Dijkgraaf en tijdens herstel van de dot.com-crisis, maakte Metro voor het eerst winst; tot de eerste jaren van de krediet-crisis bleef de krant winst opleveren. $^{26}$

In het najaar van 2003 lanceerde Metro een zaterdageditie. Publiek en adverteerders bleken echter weinig belangstelling voor die editie te hebben; in juli 2005 kwam het laatste nummer uit. Regionale edities hielden het langer uit. Een Rotterdamse versie werd in 2004 gelanceerd, een Amsterdamse een jaar later. ov-distributie werd aangevuld met andere kanalen, Metro werd ook gedistribueerd via McDonald's, in parkeergarages, supermarkten, postkantoren, ziekenhuizen en op scholen en universiteiten.

Spits werd op dezelfde dag als Metro gelanceerd maar kon niet in de NS-stations verspreid worden; in navolging van de Zweedse Metro had de uitgever een distributiecontract met de lokale vervoerder in Amsterdam (het GVB) afgesloten, en zich niet gerealiseerd dat het forenzen in Nederland een nationaal of toch minstens een Randstedelijk fenomeen is. De krant spande vervolgens een juridische procedure aan tegen Metro en de NS wegens hun exclusieve distributiecontract. Toen die geen resultaat opleverde, moest Spits de krant buiten de NSstations blijven uitdelen. Ook sloot Spits een distributiecontract af met andere lokale vervoerders en ging meer gebruik maken van distributiepunten buiten het openbaar vervoer. 
In 2012 zag Spits hoe eigenaar TMG concurrent Metro kocht. De distributie en advertentieverkoop werden in elkaar geschoven, terwijl in 2013 beide kranten ook de hoofdredacteur gingen delen. In oktober 20I4 hield Spits op te bestaan; twee gratis dagbladen bleek te veel voor de Nederlandse markt.

Waar de journalisten bij Metro het liefst een Volkskrant maakten, was er ook bij Spits sprake van een journalistieke identiteitscrisis, al manifesteerde die zich op een andere manier. Hoofdredacteur Bart Brouwers trad in 2005 aan en trof een in zichzelf gekeerde club aan die verontwaardigd was dat de wereld hen als tweederangs journalisten zag, maar daar verder niks aan deed.

'Wat ik heb geprobeerd is aan de ene kant duidelijk maken dat we inderdaad anders zijn (en dat dat juist kansen biedt) maar tegelijk de hele club wat trotser maken. Hoe vaker er over ons werd gepubliceerd (over het belang van gratis nieuws, over het nut van vermenging commercie/redactie, over de verplichting om te gaan twitteren etc.), hoe meer het tot ze doordrong dat ze ertoe deden. Dit was volgens mij minstens zo belangrijk als de primeurs waar journalisten normaal gesproken hun gezag aan ontlenen. ${ }^{27}$

Ook Spits ging het halverwege de jaren tien van deze eeuw financieel voor de wind, Brouwers: 'In 2006 en 2007 schreven we prima cijfers. Dat het uiteindelijk crisis werd, lag nauwelijks aan de komst van DAG en De Pers. Die haalden nul komma nul adverteerders bij ons weg. Ze waren wel concurrenten op de lezersmarkt, maar nooit op de advertentiemarkt.'

Eind augustus 2000 kreeg Spits een zusje, de gratis middagkrant News.nl. De distributie zou via grote kantoorcomplexen plaatsvinden. Het experiment was geen succes, in april $200 \mathrm{I}$ werd de uitgave al gestaakt, de oplage kwam nooit boven de I००.০००.

$\mathrm{Na}$ het debacle van News.nl probeerde TMG het in 2003 met Almere Vandaag. Eerder hadden Het Parool (Flevo Parool) en de Gooi- en Eemlander (Dagblad voor Almere) tevergeefs geprobeerd in Almere een betaalde krant uit te geven. Het gratis huis-aan-huisblad Almere Vandaag begon met drie keer per week, ging naar vier dagen in 2005 en een jaar later zelfs naar vijf dagen (dinsdag t/m zaterdag). In mei 2007 werd de vijfde dag weer geschrapt. De oplage was ongeveer 75.000, gelijk aan het aantal huishoudens in Almere. In juni 20I4 werd Almere Vandaag vervangen door het twee maal per week verschijnende Dichtbij Almere.

In Alphen a/d Rijn lanceerde TMG in 2004 Alphen.cc - een model dat zich van gratis tot betaalde krant zou moeten ontwikkelen. Aanvankelijk verscheen de krant drie keer per week, maar in de periode 20I0-20I2 kwamen er vier nummers per week uit. In 2013 ging men terug naar drie keer per week; eind dat jaar werd de uitgave gestaakt. De gratis oplage varieerde tussen de 20.000 en 30.000 .

Een laatste initiatief op dit gebied was Barneveld Vandaag (Wegener) dat in november 2006 het licht zag. Deze gratis krant leek met een verschijningsfrequentie van vier keer per week meer op een dagblad dan op een huis-aan-huisblad. De lancering leidde in 2007 tot een curieus kort geding dat BDU, de uitgever van de Barneveldse Krant, tegen Wegener aanspande. BDU eiste 
dat Barneveld Vandaag de onderkop 'Het dagblad van Barneveld' zou schrappen. De rechter ging met de eis akkoord. In 2008 ging Barneveld Vandaag terug naar drie dagen per week, later werd de krant omgezet in een wekelijks huis-aan-huisblad.

\section{De manie: De Pers en DAG}

De gratis-krantengekte in Nederland brak los in 2007 , toen De Pers, een gratis kwaliteitskrant die de ambitie had de grootste krant van Nederland te worden, en $D A G$, een multimediaal concept van PCM en KNP, werden gelanceerd. DAG hield het zestien maanden uit, De Pers gooide na vijf jaar de handdoek in de ring.

De Pers was een initiatief van Cornelis van den Berg die bij Wegener en bij Metro International had gewerkt en bij die laatste werkgever de smaak van gratis kranten te pakken had gekregen. Van den Berg kreeg in 2006 de ingeving om "s werelds eerste gratis kwaliteitskrant' te gaan maken en vond een financier in miljonair Marcel Boekhoorn. ${ }^{28}$ Aanvankelijk zou PCM mede-uitgever zijn. Vlak voor de ondertekening van het contract trok PCM zich echter terug, tot grote woede van Boekhoorn. Deze legt een claim van 96 miljoen neer bij РСм - een eis die later werd verlaagd tot Io miljoen en in 2010 geheel werd ingetrokken. De aanloopverliezen waarmee de krant rekening hield, bleken veel groter dan verwacht: van I2 tot I6 miljoen op jaarbasis, liep het verlies op tot 'een half miljoen per week'. ${ }^{29}$ Vooral de advertentieomzet blijft sterk achter bij de ramingen.

Uitgever Van den Berg koos voor de vlucht naar voren. Hij wilde de oplage, die medio 2008 op ruim 400.000 lag, verhogen tot I,2 miljoen - onder meer door een half miljoen kranten huis-aan-huis te verspreiden. Bovendien begon hij een zaterdagkrant (eigen redactie, eigen hoofdredacteur, eigen kantoor, afwijkend Berliner-formaat) die in 2007 en 2008 met een oplage van rond de 200.000 in Randstedelijke winkelgebieden werd verspreid. Zonder de redactie en financiers in te lichten bracht hij in het voorjaar van 2008 twee nummers van De Financiële Pers uit. Bovendien begon hij een boekenuitgeverij met geld van De Pers - opnieuw zonder redactie en financiers daarvan in kennis te stellen. ${ }^{30}$ In 2008 bedroeg het totale verlies 32 miljoen; het lot van Van den Berg was bezegeld.

Boekhoorn probeerde de krant te verkopen aan onder andere Wegener (Mecom), TMG, Metro International, PCM, NDC en Belgische en IJslandse uitgevers. Niemand wilde De Pers hebben. Toen Van den Berg uit de weg was - een 'briljante autist' volgens oud-medewerker Govert Schilling die een boek over de krant schreef - kon fors ingegrepen worden in de kosten; de oplage werd verlaagd van 370.000 in 2008 naar 220.000 in 2009. De zaterdagkrant verdween en een deel van de redactie werd ontslagen.

In 2009 kwam er redding in de figuur van Joop Munsterman van Wegener, dat voor elf jaar de uitgaverechten van De Pers overnam van Boekhoorn. Die kreeg een jaarlijkse vergoeding van minimaal I6 miljoen in ruil waarvoor Wegener advertenties voor de krant mocht verkopen. Ook ging Wegener de krant drukken en distribueren. Het contract bleek een gifpil te zijn. In 2010 moest al 63 miljoen worden afgeschreven, Munsterman moest mede door deze zeperd in 20 Io het veld ruimen. Pogingen om De Pers een andere koers te laten varen (zo werd overwogen om er een Nederlandse tabloid naar model van The Sun van te maken) mislukten en op 30 maart 20io viel het doek voor de krant. Het contract met Boekhoorn werd afgekocht voor 
45 miljoen. De Pers ging als De Nieuwe Pers online verder - eind 2013 veranderde de titel in TPO Magazine, de betaalde online versie van The Post Online.

Op dat moment was het 'mediumonafhankelijk nieuwsplatform' DAG al verdwenen. De Volkskrant-plannen voor een gratis krant gaan terug tot 2002 toen men zonder resultaat een bod deed op aandelen van de Nederlandse Metro. In 2004 werden plannen gemaakt voor de gratis krant Moment die in een oplage van I,5 miljoen drie dagen per week na 9:00 via supermarkten verspreid zou moeten worden. In 2006 liet de uitgever twee parallelle plannen ontwikkelen om een eigen gratis krant te beginnen - ook omdat men met scheve ogen keek naar nrc.next van concurrent en concern-genoot NRC Handelsblad. Daarnaast had PCM-voorman Aan de Stegge ook nog een afspraak met Marcel Boekhoorn om samen diens gratis krant uit te gaan geven. ${ }^{3 \mathrm{I}}$

De PCM-plannen waren op z'n minst divers, een strategie ontbrak, terwijl diverse geledingen in het bedrijf zo hun eigen ideeën hadden over de nieuwe uitgave die in mei 2007 het daglicht zag. Volkskrant-hoofdredacteur Pieter Broertjes en CEO Aan de Stegge botsten in het openbaar over de strategie. Nieuw aan de uitgave was dat er stevig ingezet werd op multimedia; lezers werden doorverwezen naar de website voor filmpjes en extra informatie. Voor deze features was een samenwerking met KPN aangegaan, maar in de praktijk werkte het multimediale deel maar matig, na een half jaar trok KPN zich dan ook terug als leverancier van content. Binnen een jaar werd de koers van DAG omgegooid: meer doorgeplaatst Volkskrantmateriaal, minder foto's, een ander design, minder multimedia en inzetten op een hoger opgeleide doelgroep. Het mocht niet baten. De kosten waren hoog, de verliezen liepen op en de inkomsten vielen tegen. Eind september 2008 hield de papieren krant op te bestaan, de online versie ging nog een jaar door. PCM heeft uiteindelijk minstens € 20 miljoen verlies geleden met het project. ${ }^{32}$

De korte levens van De Pers en DAG waren veelbewogen, de kosten werden onbeheersbaar, de ramingen over lezers en adverteerders bleken te optimistisch, ambities over oplage, multimedialiteit en content konden niet worden waargemaakt. Uit de twee boeken die over De Pers verschenen en de reconstructie van de opkomst en ondergang van DAG rijst een wonderlijk beeld op van wanbeleid gekoppeld aan een grenzeloos enthousiasme. ${ }^{33}$ Het is echter de vraag of de ondergang te wijten was aan bedrijfsmatige stuurloosheid. De Pers en DAG waren wel degelijk de derde en vierde gratis krant op de landelijke markt. Door de economische crisis van 2008 stortte de advertentiemarkt in; voor een medium dat volledig afhankelijk is van adverteerders is dat al snel fataal.

\section{Oplage en lezers}

De oplage van de gratis dagbladen steeg vrijwel voortdurend, van 500.000 in I999 tot I,8 miljoen in 2007. ${ }^{34}$ Dat kwam vooral doordat Metro en Spits hun distributienetwerk uitbreidden, beide titels begonnen in de Randstad, en breidden hun gebied vervolgens uit naar de rest van Nederland. In 2008 daalde het aantal exemplaren marginaal, doordat De Pers de oplage terugschroeft. Daarna was een snellere daling waar te nemen, eerst door de stuiting van DAG, maar ook doordat Metro en Spits hun oplages verminderden. Om efficiëntie te realiseren sneed men in het distributienetwerk: na 9:00 moesten de verdeelbakken leeg zijn, de plaatsen waar te 
weinig kranten werden meegenomen of waar de jongere doelgroep niet of onvoldoende komt, werden geschrapt. Zo besloot Spits te distributie in ziekenhuizen en verzorgingshuizen te staken, omdat die doelgroep niet interessant is. Groei en concurrentie maakten plaats voor efficiency. Met het einde van De Pers in 20I2, daalde het aantal gratis kranten tot onder de 800.000; in 2015 zal de oplage van Metro - de enig overgebleven gratis krant - volgens de uitgever ruim 500.000 bedragen (figuur 2).

De ontwikkeling van het aantal lezers van gratis dagbladen loopt ongeveer parallel aan de ontwikkeling van de oplage. Door gegevens over oplage (HOI) en bereik (NOM) te combineren, kan berekend worden hoeveel lezers één exemplaar van een krant bereikt. Bij betaalde kranten bereikt één nummer gemiddeld drie lezers. Bij gratis kranten is dat hoger, omdat kranten blijven liggen in het openbaar vervoer en vervolgens door andere lezers worden gepakt. Spits had in zijn laatste jaren tussen de vier en vijf lezers per nummer. Bij Metro varieerde het tussen drieënhalf en vier. Bij Metro en Spits stegen de oplage en het aantal lezers tot 2007. De oplage steeg ook in 2008 maar het aantal lezers daalde. De komst van De Pers en DAG is daar debet aan. Metro bereikte zijn hoogtepunt qua bereik in 2007 met bijna twee miljoen lezers, Spits had er toen I,8 miljoen; De Pers en DAG zaten beiden tussen de 600.000 en 800.000 lezers (figuur 3).

In 2008/2009 werd het bereik van alle gratis kranten bij elkaar voor het eerst gemeten door NOM Print Monitor. Toen bleek dat er een grote overlap zit tussen de lezerskringen van gratis kranten. DAG bestond toen niet meer, Metro had I,9 miljoen lezers, Spits I,7 miljoen en De Pers 900.000. Samen bereikten de drie titels geen 4,5 maar 'slechts' 2,9 miljoen Nederlanders. Ruim de helft, bleek dus meerdere titels te lezen. Voor 2013 zien we: I,8 miljoen totaal en I,3 en I,2 miljoen lezers voor respectievelijk Metro en Spits. Een half miljoen lezers pakte dus dagelijks beide titels.

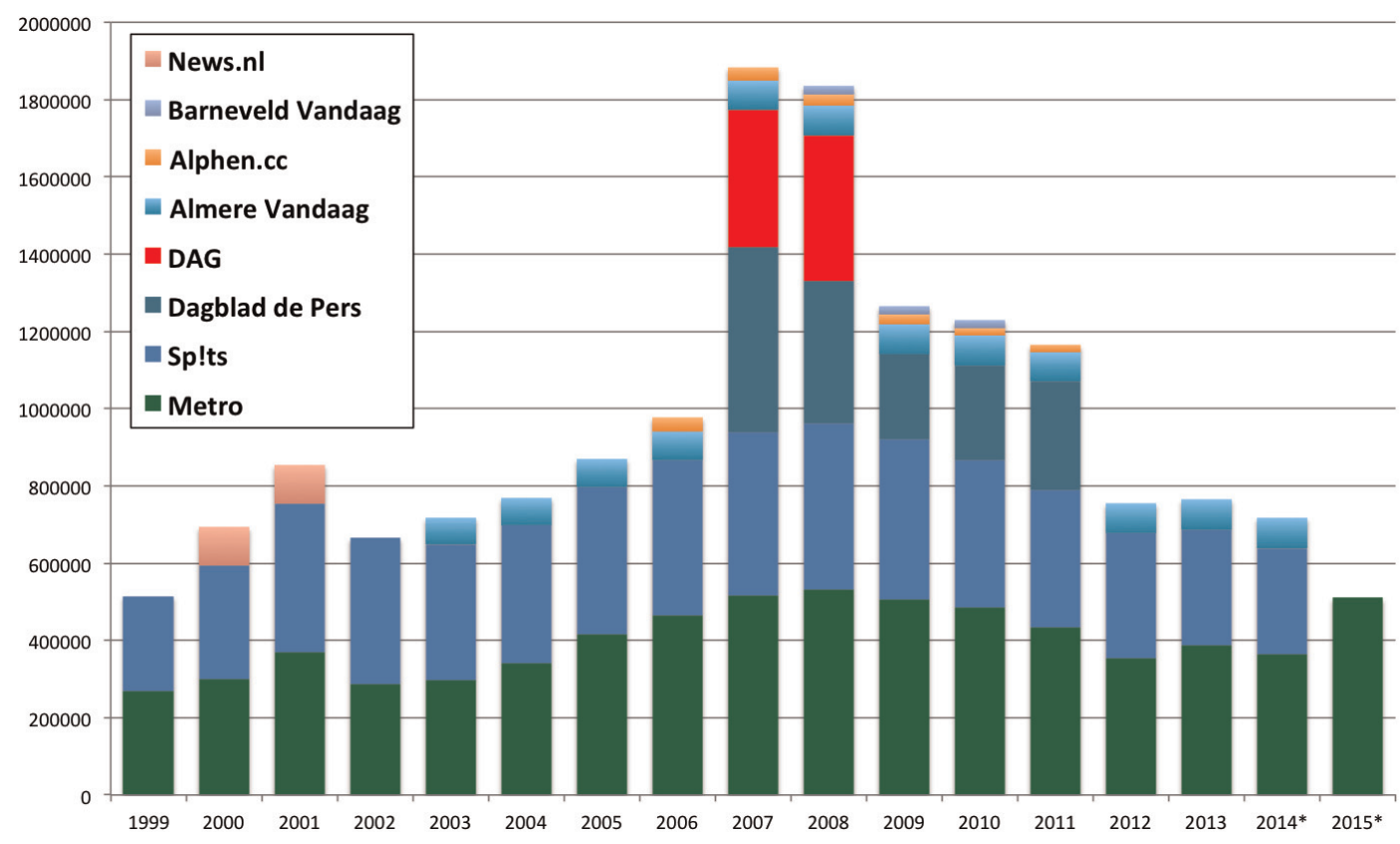

Figuur 2. Gratis dagbladen in Nederland 1999-2015: oplage en titels. Bron: opgave uitgevers $t / m$ 20012; daarna Hoi-online.nl

* 2014: eerste half jaar; 2015: opgave uitgever. 


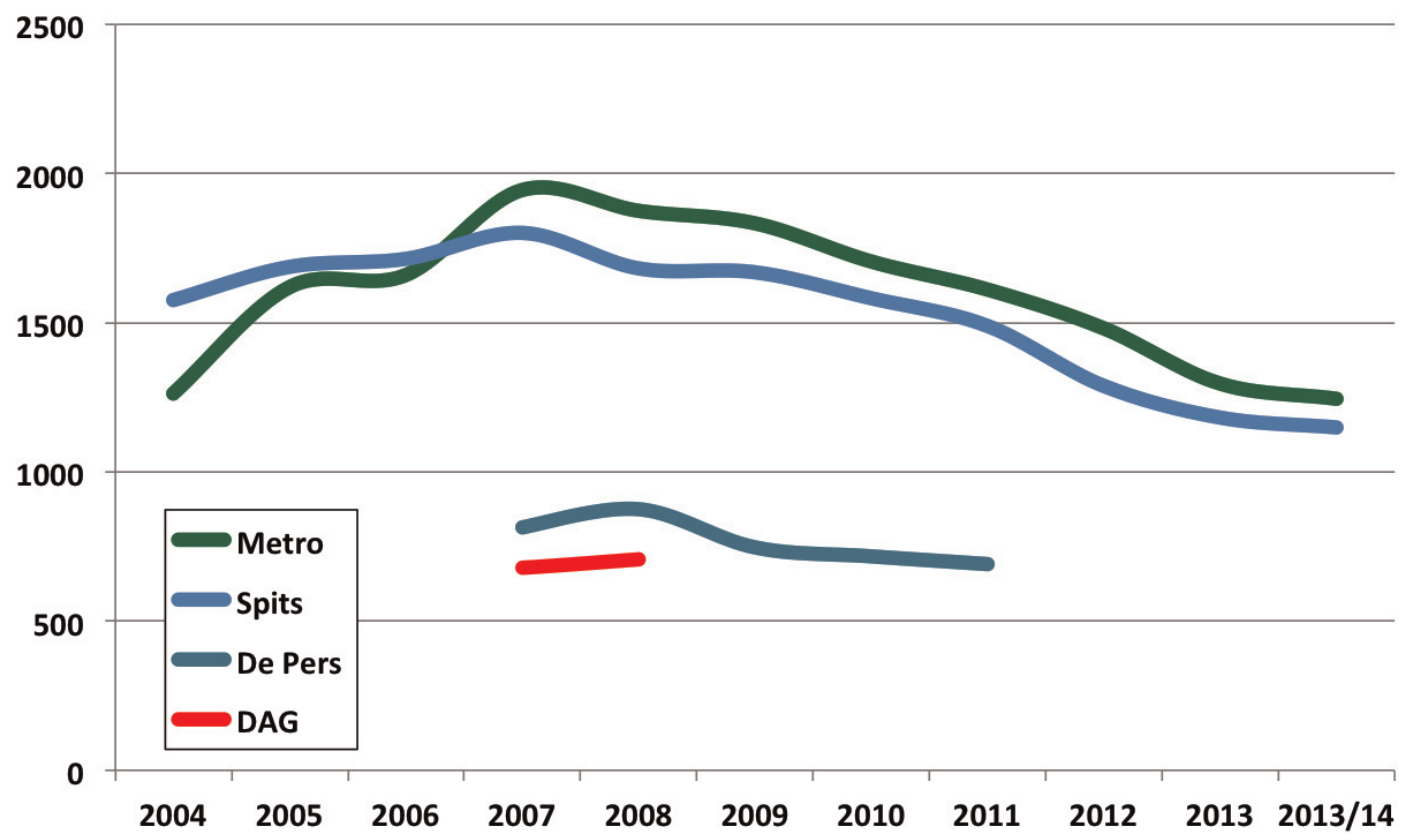

Figuur 3. Het lezen van gratis dagbladen in Nederland 2004-2014 (x 1000). Bron: NOM Print Monitor.

In 2013 las 57 procent van de Nederlandse bevolking van dertien jaar en ouder dagelijks een krant, ruim 5I procent leest een betaalde krant. Dat zijn hoge percentages - ook in een Europese context waar Nederland samen met de Scandinavische landen, Duitstalige landen en GrootBrittannië tot de top behoort. Het krantenlezen neemt overigens wel af; tien jaar geleden lagen deze percentages rond de 70 procent $(67 \%$ betaalde kranten, $73 \%$ inclusief gratis kranten, zie

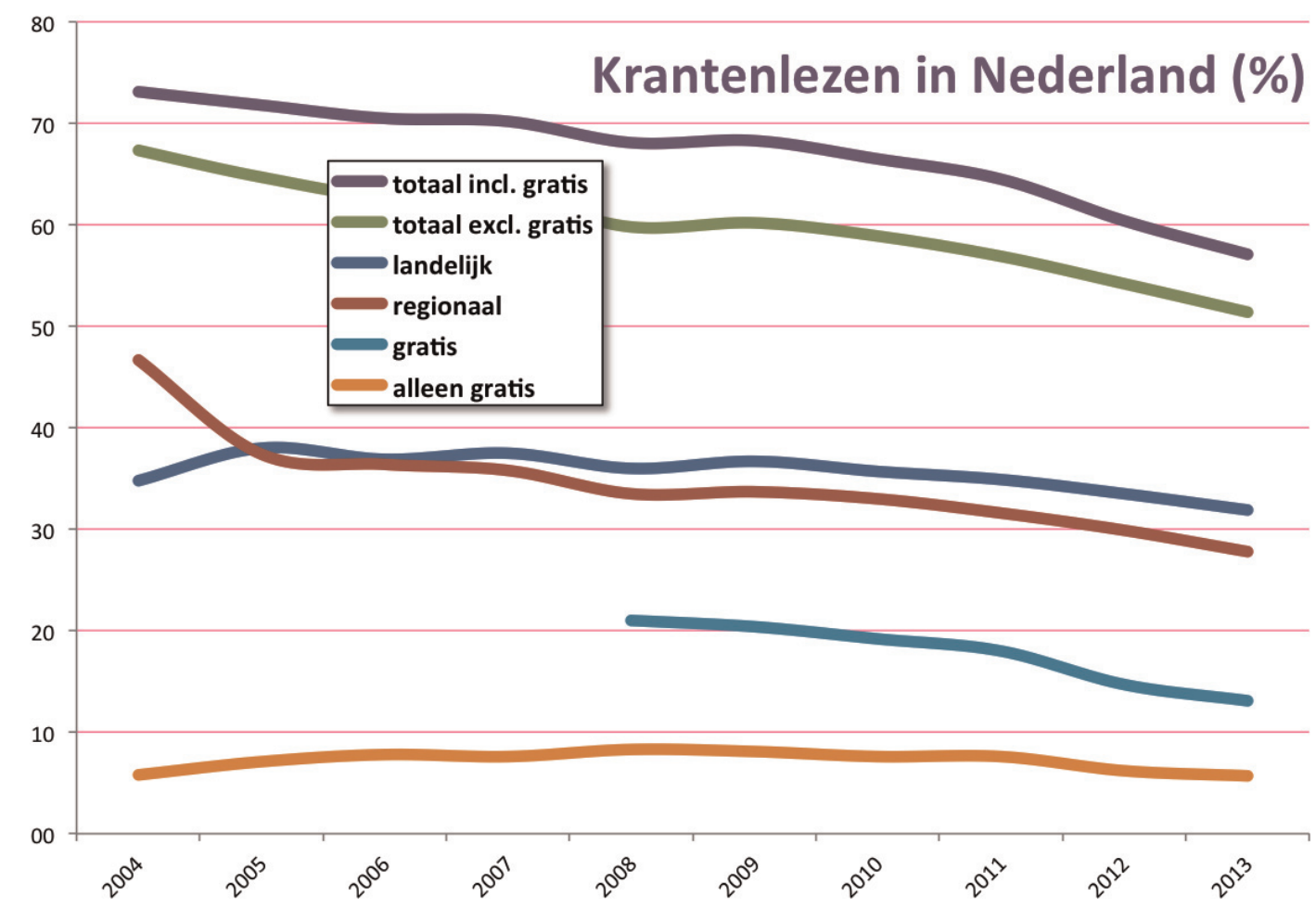

Figuur 4. Lezen van betaalde en gratis dagbladen in Nederland. Bron: NOM Print Monitor. 


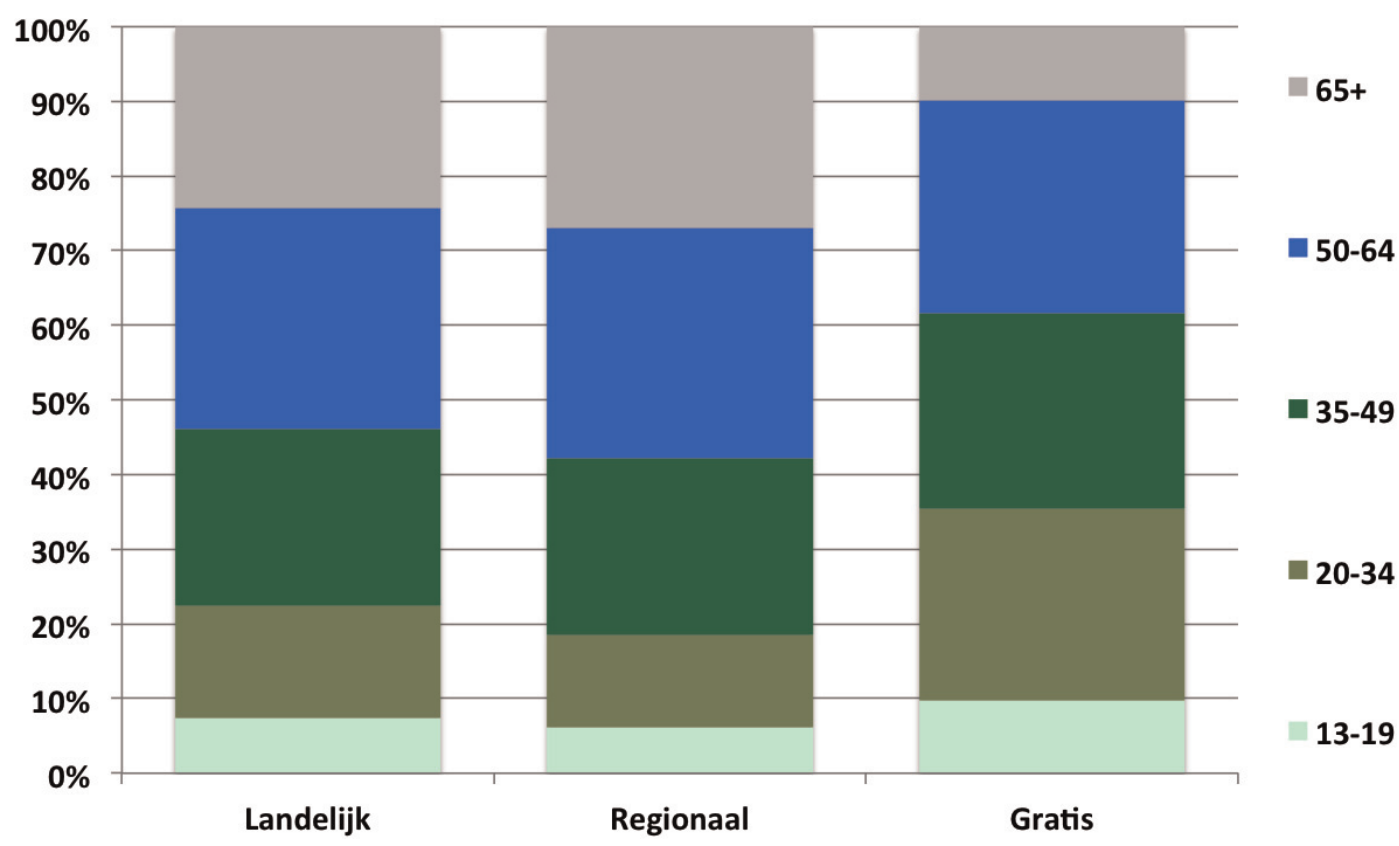

Figuur 5. Leeftijd van lezers van betaalde en gratis dagbladen in Nederland 2012. Bron: NOM Print Monitor.

figuur 4). Dubbellezen van gratis en betaalde kranten komt vaak voor. Ongeveer 6o procent van de lezers van gratis kranten las ook een betaalde krant in de periode 2008-20I3.

Lezers van gratis kranten zijn jonger dan lezers van betaalde kranten. Bij landelijke kranten was in 201222 procent van de lezers jonger dan 35 jaar, 24 procent ouder dan 65 . Voor regionale kranten waren deze percentages i8 en 27. Daarentegen was 36 procent van de lezers van Metro en Spits jonger dan 35 jaar, terwijl slechts Io procent ouder dan 65 is. Hoewel de lezerskringen verschillen, maakt de grafiek ook duidelijk dat er geen sprake is van totaal verschillende lezers voor beide modellen (figuur 5). De verschillen tussen manlijke en vrouwelijke lezers en tussen lezers van divers welstandsniveau (combinatie van opleiding, inkomen en sociale klasse) blijken klein.

\section{Effecten op de betaalde oplage}

Voor uitgevers was het altijd de vraag of gratis kranten kannibaliseren op de betaalde oplage. Analyse van Europese gegevens leverde in eerder onderzoek slechts in enkele uitzonderlijke gevallen (IJsland, Denemarken) aanwijzingen op voor substitutie. ${ }^{35}$ Probleem bij de analyse van Nederlandse cijfers is dat deze pas sinds I999 - dus het jaar van de introductie van de gratis krant - op een vergelijkbare manier worden verzameld. Bovendien valt die periode samen met de introductie van internet in Nederland. Wel valt op dat de betaalde oplage in 2000 en 200 I niet extra hard gaat dalen (vanwege het abonnementensysteem is een effect pas na een jaar zichtbaar). Ook de introductie van De Pers en DAG leidt niet tot extra daling; hun einde levert ook geen hogere oplage op voor betaalde kranten (figuur 6). 


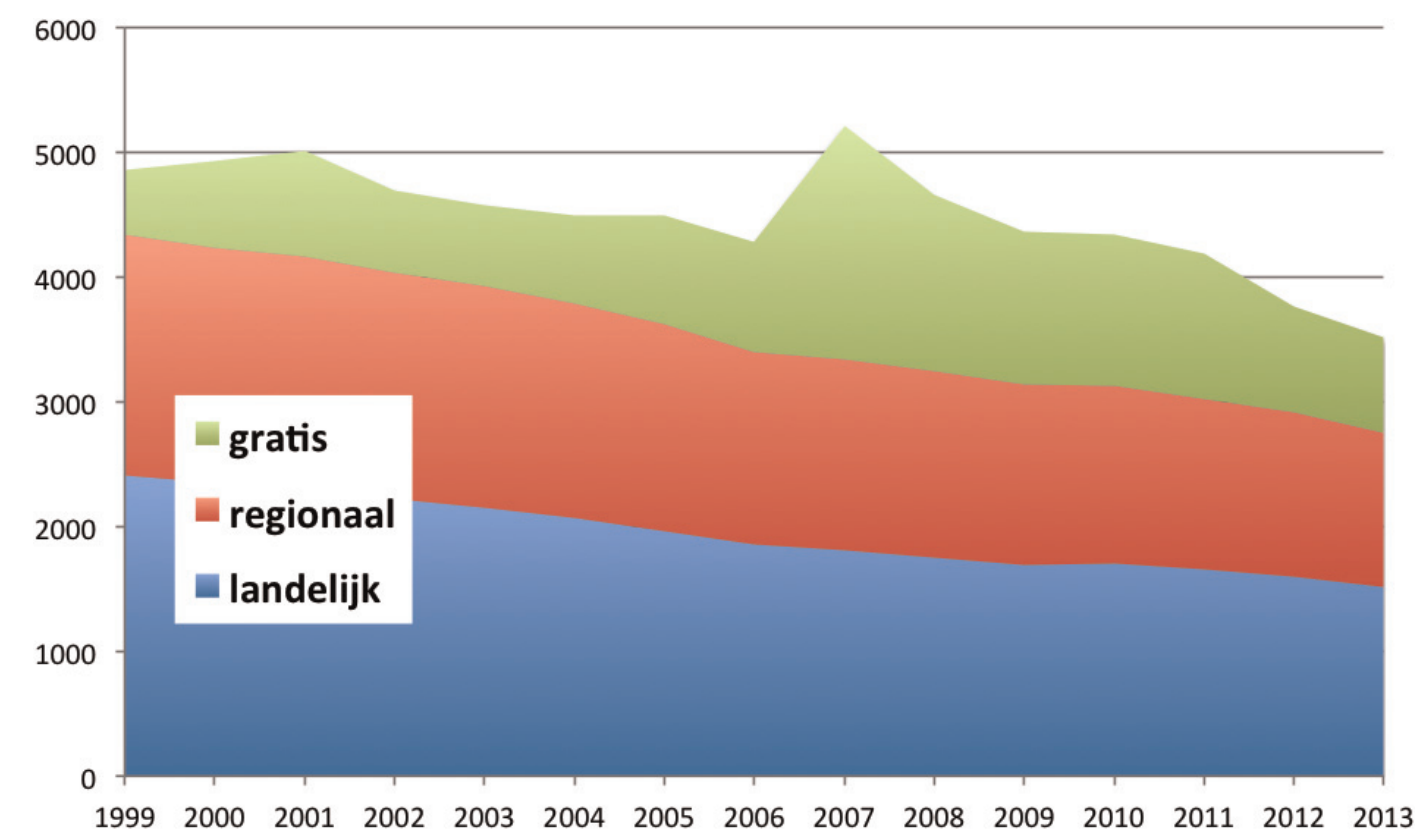

Figuur 6. Oplage van betaalde en gratis dagbladen in Nederland. Bron: Hoi-online.nl.

\section{Conclusie}

Gratis kranten in Nederland volgen een patroon dat vergelijkbaar is met dat in andere Europese landen: een sterke groei tot 2008 en sluiting van titels en dalende oplagen daarna. Vrijwel nergens in West-Europa is de gratis krant overigens uitgestorven. Er lijkt in de meeste markten ruimte te zijn voor één en soms zelfs voor twee titels. Wat gratis kranten 'doen' voor een markt is dat ze het totaal aantal lezers doen toenemen. Die lezers zitten voor een belangrijk deel in jongere doelgroepen die zonder een gratis krant geen krant zouden lezen.

Het life cycle model is van toepassing op de opkomst en ondergang van zowel betaalde als gratis kranten. In het geval van betaalde kranten is het de publieksvoorkeur die rechtstreeks de oplage beïnvloedt, bij gratis kranten beïnvloeden publieksvoorkeur en de economische situatie de advertentie-exploitatie en daarmee ook het bestaansrecht van de desbetreffende titel. De 'niche' theorie suggereert dat gratis en betaalde kranten zo veel van elkaar verschillen dat ze een ander publiek aanspreken. Dit wordt in Nederland niet door empirische bewijzen ondersteund. De lezers van gratis en betaalde kranten verschillen vooral qua leeftijd, maar voor een deel overlappen die elkaar. Die overlap (substantiële groep 'dubbellezers') leidt niet tot grootschalige substitutie. Adverteerders houden wel rekening met die optie. Zij kunnen de verschillende modellen probleemloos wisselen, al naar gelang de doelgroep die zij willen bereiken. Dat leidt dan weer tot druk op advertentietarieven en tot de situatie die we in Nederland nu kennen: na een stormachtige opkomst en ontwikkeling, een situatie waarin één titel overblijft.

De digitale voorkeur van opkomende generaties die een afnemende belangstelling voor betaalde kranten verklaart, zou ook de gratis krant parten kunnen gaan spelen. De vijftien tot twintig minuten die de forens aan de Metro besteedt, kan namelijk ook gevuld worden met smartphone of tablet. ${ }^{36}$ In Nederland gebruikte in 2013 al 50 procent van de bevolking van dertien jaar en ouder een smartphone, ruim 35 procent gebruikt een tablet. ${ }^{37}$ Dat doet 
vermoeden dat de gratis krant inderdaad het life-cycle model volgt en dat er van opwaartse trend geen sprake meer zal zijn.

\section{Noten}

I. H. Arlman, G. Mulder \& U. den Tex, De val van de Rode Burcht, De Arbeiderspers, Amsterdam i980; P. v.d. Hoeven, Het succes van een kwaliteitskrant; De ontstaansgeschiedenis van NRC Handelsblad, Prometeus, Amsterdam 20I2; F. v. Vree, De metamorfose van een dagblad. Een journalistieke geschiedenis van de Volkskrant, Meulenhof, Amsterdam I996; J. Wieten, Dagblad En Doorbraak: De Nederlander En De Nieuwe Nederlander, Kok, Zwolle I986.

2. H. J. Scheffer, Henry Tindal. Een ongewoon heer met ongewone besognes, Fibula/Van Dishoeck, Bussum I976; M. Wolf, Het geheim van De Telegraaf, Boom, Amsterdam 2009.

3. R. Vernon, 'International Investment and International Trade in the Product Cycle', in: The Quarterly Journal of Economics, 2, vol. 80, I966, p. I90-207.

4. J. van Zuilen, The life cycle of magazines: A historical study of the decline and fall of the general interest mass audience magazine in the United States during the period 1946-1972. Graduate Press, Uithoorn 1977.

5. R. G. Picard, 'Shifts in Newspaper advertising expenditures and their implications for the future of newspapers', in: Journalism Studies, 2008, iFirst Article, I-I3 [Electronic version], p. I2.

6. World Press Trends, World Association of Newspapers, Paris 2000-2013.

7. E. Lauf, 'The vanishing young reader: Sociodemographic determinants of newspapers use as a source of political information in Europe I980-98', European Journal of Communication, vol. I6, 200I, p. 233-243; P. E. Meyer, The Vanishing Newspaper: Saving Journalism in the Information Age, University of Missouri Press, Columbia 2004.

8. C. Christensen, The Innovator's Dilemma: When New Technologies Cause Great Firms to Fail, Harvard Business School Press, Boston 1997.

9. J. Dimmick \& E. Rothenbuhler, The theory of the niche: Quantifying competition among media interests, in: Journal of Communication, vol. 34, I984, p. Io9-II9.

Iо. P. Bakker, 'The life cycle of a free newspaper business model in newspaper-rich markets', Journalistica, I, 2013, p. 33-5I.

II. Een 'dagblad' wordt gedefinieerd als een uitgave die minstens vier dagen per week uitkomt. Deze definitie sluit aan bij die van de World Association of Newspapers (World Press Trends, 2000-2013). In Nederland is het gebruikelijk uitgaven die minstens vijf keer per week verschijnen als dagblad te beschouwen. Zoals we in dit artikel zullen zien heeft dit onderscheid voor de Nederlandse beschrijving wel gevolgen.

I2. M. Haller, Gratis-Tageszeitungen in den Lesermärkten Westeuropas, Nomos Verlag, Baden-Baden 2009.

I3. J. Gibbs, 'The Berlin Newspaper Der Panzerbär, April I945', in: Media History, 2, vol. I4, 2008, p. 205-22I; D. Irving, Goebbels; Mastermind of the Third Reich, Parforce Ltd., London I996, p. 9II-9I3.

I4. R. Greenslade, Press Gang - How Newspapers Make Profits From Propaganda, Macmillan, London 2003.

I5. J. v.d. Plasse, Kroniek Van De Nederlandse Dagbladpers, Otto Cramwinckel Uitgeverij, Amsterdam 2000.

I6. S. Larsson, 'The paper that took the subway to the readers' (eerst gepubliceerd in Makt Q Media, I996) gedownload van http://www.a4.net/artikel.asp?id=2I2\&eng=I; I. Wadbring, En tidning $i$ tiden; Metro och den svenska dagstidningsmarknaden, Institutionen för Journalistik och Masskommunikation, Göteborg 2003.

I7. P. Bakker, 'Free Daily Newspapers - Business Models and Strategies', in: JMM, Journal of Media Management, 3 , vol. 4, 2002, p. I80-187; R. G. Picard, 'Strategic responses to Free Distribution Daily Newspapers', in: JMM Journal of Media Management, 3, vol. 2, 2000, I67-I72.

I8. E. Sporstøl, Free Papers in Spain: 20 Minutes of Fame or here to stay? Thesis Norwegian School of Management, 2003; Larsson, 'The paper that took the subway to the readers'; Wadbring, En tidning i tiden.

I9. A. Vogel, 'Die tägliche Gratispresse; Ein neues Geschäftsmodell für Zeitungen in Europa', in: Media Perspektiven, II, 200I, p. 576.

20. L. Wilcox, 'Metro, info, haro! Fierce reactions to regime competition in the French newspaper industry', in: Media, Culture Q Society, 3, vol. 27, 2005, p. 356.

2I. A. Kammer, Gratisaviserne som politisk resource, Master thesis Københavns Universitet, 2009.

22. D. C. Hallin \& P. Mancini, Comparing media system; Three models of media and politics, Cambridge University Press, Cambridge 2004 .

23. Bakker, 'The life cycle of a free newspaper business model in newspaper-rich markets'.

24. Interview, 6 november 2014 . 
84 Tijdschrift voor Mediageschiedenis - I8 [I] 20 I5

25. Interview, 6 november 2014

26. Metro International, Annual Reports, 2000-2013.

27. Interview, 7 november 2014 .

28. C. v.d. Berg, Het Complot, Prometeus, Amsterdam 20II, p. I7.

29. Idem, p. I3.

30. G. Schilling, Gratis maar niet goedkoop; de kostbare wording van Dagblad De Pers, Atheneum / Polak \& Van Gennep, Amsterdam 2010.

3I. B. Logger \& R. de Vries, De Laatste Krant; Dag: het miljoenenverslindende huwelijk tussen PCM en KPN, Podium, Amsterdam, 20II.

32. Logger \& De Vries, De Laatste Krant; J. Ramaer, De Geldpers; De teloorgang van het mediaconcern PCM, Prometeus, Amsterdam 2010.

33. Van den Berg, Het Complot; Schilling, Gratis maar niet goedkoop; Logger \& De Vries, De Laatste Krant; Ramaer, De Geldpers.

34. In 2002 lijkt er een daling te zijn, maar dat komt omdat vanaf dat jaar de titels de oplage officieel door het HOI laten meten; daarvoor is de oplage gebaseerd op de - kennelijk nogal optimistische - opgaves van de uitgevers zelf. 35. P. Bakker, 'The simultaneous rise and fall of free and paid newspapers in Europe', Journalism Practice, 2, p. 427-443, 2008.

36. I. Costera Meijer \& T. Groot Kormelink, 'Checking, Sharing, Clicking and Linking; Changing patterns of news use between 2004 and 20I4', in: Digital Journalism, iFirst article, I-I6, 20I4. DoI: IO.Io80/2I6708Ir.20I4.937I49.

37. De Media Standaard Survey (MSS) waarin Nationaal Luisteronderzoek (NLO), Nationaal Onderzoek Multimedia (NOM) en Stichting Kijkonderzoek (sко) participeren laat een sterke groei van gebruik van tablets en mobiel zien. Het tabletgebruik (internetten) was $35 \%$ in 2013 tegen $8 \%$ in 20 II (bevolking I3 jaar en ouder). Smartphonegebruik ging van 27 naar 49\%. Bron: Rapportage 2013 Media Standaard Survey (MSs). Bron: https://kijkonderzoek.nl/ images/MSs/MSs_rapportage_20I3.pdf 